\title{
EL CUERPO FEMENINO: RETÓRICA Y ARGUMENTACIÓN EN LA POESÍA MISÓGINA MEDIEVAL
}

\author{
Henry Campos Vargas
}

Si de algo jamás te arrepentirás, es de haber aprovechado el tiempo

A mi ahijada María Fernanda

\begin{abstract}
RESUMEN
La retórica clásica ofrece distintos principios para los discursos epidícticos y deliberativos. Este artículo procura aplicarlos para comprender el papel del cuerpo femenino en algunos poemas misóginos de la Edad Media desde un punto de vista argumentativo.

Palabras clave: retórica clásica, literatura medieval, discurso epidíctico, argumentación, poemas misóginos.
\end{abstract}

\section{ABSTRACT}

Classic rhetoric offers different principles for epideictic and deliberative discourse. This paper applies them to understand the role of female body in some misogynistic poems of Medieval Age from an argumentative point of view.

Key words: classic rhetoric, Medieval literature, epideictic discourse, argument, misogynistic poems.

\section{El género epidíctico y el vituperio}

Entre los tres géneros retóricos aristotélicos (Aristóteles 1999: 193-194, 1358a36$1358 \mathrm{~b} 8$, concepto expresado por este pensador indistintamente mediante las voces génos y eîdos), la poesía no encontraba un lugar propio en los ámbitos judicial o deliberativo. Su espacio quedaba reservado al género epidíctico, es decir, a aquel discurso retórico cuyo objeto

ML. Henry Campos Vargas. Profesor de la Escuela de Filología, Lingüística y Literatura de la Universidad de Costa Rica.

Correo electrónico: hcamposv@yahoo.es

Recepción: 04- 03- 2013

Aceptación: 19- 04- 2013 
es el elogio y la censura (Aristóteles: 194, 1358b 13), su auditorio estaba constituido por espectadores, no por jueces vinculados a un proceso o a una deliberación política, el tiempo era el presente"aunque muchas veces puede actualizarse lo pasado por medio de la memoria y lo futuro usando de conjeturas" (Aristóteles 1999: 195, 1358b20) y su fin, lo bello y lo vergonzoso.

Esta clasificación ya aparece en la Retórica a Alejandro, obra atribuida por la mayoría de los estudiosos a Anaxímenes de Lámpsaco, en la que se distinguen estos mismos tres géneros retóricos (llamados por este autor génos) de sus siete especies (ê̂dos): suasoria, disuasoria, laudatoria, vituperadora, acusatoria, exculpatoria e indagatoria (Alcidamente y Anaxímenes 2005: 207).

Una de las diferencias más relevantes entre estas dos obras radica en que Anaxímenes de Lámpsaco descubre y reconoce que es posible el empleo de cualquiera de las especies retóricas en los distintos géneros, así se lee en su obra: "Ese es el número de las especies de discursos (a las que él llama ềdos). Las usaremos en los discursos deliberativos, en los judiciales sobre contratos y en las declamaciones privadas" (Alcidamente y Anaxímenes 2005: 207).

Otra diferencia que conviene destacar consiste en que Aristóteles no ofrece una dispositio especial para el género epidíctico, pues opera con un modelo común a los tres géneros. En cambio, la Retórica a Alejandro propone un modelo común a los géneros deliberativo y judicial, y uno particular para el epidíctico. El desarrollo de esta propuesta será muy fecundo en la antigüedad y encontrará su culminación en los dos tratados sobre retórica epidíctica atribuidos a Menandro de Laodicea, también conocido como Menandro el Rétor.

Ahora bien, en la antigüedad, es raro el tratado de retórica que se ocupe específica y particularmente del vituperio, discurso que será ampliamente desarrollado en los discursos misóginos medievales. Aristóteles, por ejemplo, no hace una propuesta específica al respecto, pues recurre a un principio general que enuncia así:

Porque, en efecto, conociendo estas nociones [se refiere a los principios del elogio], también sus contrarios se hacen evidentes; pues la censura <procede> de tales contrarios. (1999: 254, 1368a35-37)

De esta manera, mediante una "inversión" de los principios relativos al elogio, el lector obtendría los del vituperio (psógos). Algo semejante ocurre en las dos obras atribuidas a Menandro el Rétor, donde se lee:

\footnotetext{
Así que los epidícticos son el vituperio y la alabanza - pues las exhibiciones de discursos públicos que hacen los llamados sofistas pensamos que son ejercicios de declamación con fines prácticos, no una exhibición-.

Pues bien, la clase del vituperio es indivisible; una alabanza, en cambio, lo es o en honor de dioses, o de seres mortales. Cuando en honor de dioses, las llamamos "himnos", y los clasificamos, a su vez, según el dios. Así, a los de Apolo los denominamos "peanes" e "hiporquemas"; a los de Dioniso, "ditirambos" y "iobacos" y con cuantos nombres parecidos se aplican a los de Dioniso; a los de Afrodita, "eróticos"; a los en honor a los demás dioses, o bien, por su denominación genérica, los llamamos "himnos" o, más específicamente, "en honor de Zeus" por ejemplo. (1996: 88, 331,15-332,4)
}

He aquí las únicas menciones en esta obra a esta importante variable del género epidíctico, del cual solo se dice que es indivisible, lo que es lógico, ya que el elogio es clasificado con base en la oposición inmortales/mortales, la cual no tiene lugar en el primero, pues no es usual insultar a un dios.

Otros retóricos como Teón y Aftonio, en sus Ejercicios de Retórica, apelan igualmente a la "inversión" de técnicas para prescindir del desarrollo de una propuesta respecto del vituperio (al respecto puede consultarse Teón y Aftonio 1991: 128.112 y 242.27). 
En cambio, la Retórica a Alejandro, en el ámbito griego, y la Retórica a Herenio, en el romano, se apartan de este proceder. La primera, por ejemplo, dispone que "[...] quien vitupera tiene que hacer la genealogía con los antepasados malvados" (Alcidamente y Anaxímenes 2005: 274, 35.10), más adelante agrega:

\begin{abstract}
Cuando narremos los hechos de personas malvadas, organizaremos las acusaciones del mismo modo. No debemos burlarnos de aquel a quien vituperamos, sino contar pormenorizadamente su vida. Pues los argumentos convencen a los oyentes y afligen a los vituperados más que las burlas. Pues las burlas ponen su punto de mira en el aspecto y en la naturaleza del individuo, mientras que los argumentos son como representaciones de su carácter y su forma de ser.

Procura no contar hechos desvergonzados con palabras desvergonzadas, para no denigrar tu carácter, sino solo sugerirlos y, utilizando palabras que se refieren a otras cosas, dejar patente el hecho.

También es necesario en los vituperios ironizar y reírse del adversario, de lo que él se enorgullece; y, en privado o ante pocos presentes, deshonrarlo, pero ante la masa, lanzar acusaciones perfectamente generales. Es necesario amplificar y aminorar los vituperios del mismo modo que los elogios. A partir de estos recursos, conoceremos la utilización de estas especies. (2005: 275-276, 35.17-19)
\end{abstract}

Por su parte, la Retórica a Herenio es la que desarrolla de manera más amplia y directa lo concerniente al vituperio en el género demostrativo, nombre que entre los romanos recibió el epidíctico. De acuerdo con esta obra, tres son los grandes aspectos que han de considerarse al componer un elogio o un vituperio: primero, las circunstancias externas al individuo, en segundo término, sus atributos físicos y, por último, sus cualidades morales (Anónimo 1997: 181, III.10).

Para el autor de esta obra, las circunstancias externas se caracterizan por originarse en el azar o la fortuna, por lo cual enlista aspectos como el linaje, la educación, la riqueza, los recursos, el renombre, la patria y las amistades. Los atributos físicos son las características del cuerpo, entre las que destacan la fuerza, la belleza y la salud. Las cualidades morales, en cambio, dependen del juicio y reflexión de la persona, entre las que se cuentan la sabiduría, la justicia, el valor y la moderación. Cabe destacar que este último elenco aparece vinculado en la obra con la demostración y la refutación, temas propios de ámbitos argumentativos (Anónimo 1997: 182, III.11).

Los exordios de los discursos demostrativos (es decir, epidícticos) son directos, pues su objeto no es dudoso, sino cierto. Para su elaboración, puede partirse de cuatro ejes distintos: "nuestra persona, la persona de que hablamos, de nuestros oyentes o del tema mismo" (Anónimo 1997: 182, III.11). En el primer caso,

Para censurar diremos que tenemos motivos para hacerlo por la manera en que fuimos tratados; o que lo hacemos voluntariamente porque consideramos útil que todos conozcan una maldad y perversidad sin parangón; o porque censurando a otros queremos mostrar aquello que nos desagrada. (Anónimo 1997: 182, III.11)

En cambio, al tomar como referencia a la persona de que hablamos, en el exordio debe expresarse lo que pueda decirse en contra de ella, por ejemplo, en cuanto a sus valores y logros.

Respecto de la censura que atiende a los oyentes,

[...] utilizaremos los recursos contrarios; puesto que lo conocen bien, diremos que vamos a extendernos poco sobre la maldad del acusado; pero si no lo conocen, les pediremos que lo conozcan para que puedan evitar su perversidad; dado que los oyentes no se parecen a la persona que censuramos, confiamos en que rechazarán enérgicamente su conducta. (Anónimo 1997: 182, III.12)

La mención del "acusado" no deja de establecer una asociación de este discurso con el judicial, ello no es de extrañar, ya que en esta misma obra se indica que

[...] aunque no es frecuente tratar este tipo de causas individualmente, en las causas judiciales y deliberativas el elogio o la censura ocupan con frecuencia un lugar importante. Por ello pensé que debía dedicar también a esta clase de causas una parte de mis esfuerzos. (Anónimo 1997: 186, III.15) 
Al tratar del exordio basado en el propio tema, la obra recurre al principio general de negación de los principios del elogio, que en este caso implicaría recurrir a una duda retórica sobre lo que se debe censurar, con la expresión de cierto temor de omitir muchas de las que podrían citarse.

El examen de la narración también ofrece cierto grado de profundidad: primero, se describirán los hechos de acuerdo con el orden y momento en que acontecieron, esto permitiría "entender lo que hizo esa persona y la prudencia y habilidad que mostró. Pero antes deberemos presentar sus virtudes o defectos y, luego, explicar cómo su carácter logró sacar partido de esas ventajas o inconvenientes físicos y de las circunstancias externas" (Anónimo 1997: 184, III.13).

Seguidamente, se considerará la ascendencia, aspecto catalogado como circunstancia externa en esta obra, la cual en la censura implica lo siguiente:

[...] si procede de buena familia, se dirá que ha deshonrado a sus antepasados; si es de baja extracción, que aun
así los ha envilecido. Educación: como elogio, que durante toda su infancia ha sido educado en los valores de
la honestidad y la virtud; como censura, que se apartó abiertamente de ellos. (Anónimo 1997: 184, III.113)

Prosigue el vituperio en atención a las calidades físicas, el cual comporta afirmar

que ha abusado de ellas [si las tenía], que como cualquier gladiador las debe al azar y a la naturaleza. Si carece de ellas, salvo en lo que se refiere a la belleza, diremos que todas le faltan por su propia culpa y excesos. (Anónimo 1997: 184-5, III.14)

A continuación, la Retórica a Herenio recomienda volver a las circunstancias externas para examinar la virtudes y defectos que se han mostrado a lo largo de la vida, por ejemplo, en el ejercicio de cargos públicos, en sus relaciones de amistad, etcétera: "[...] en el caso de censura, afirmaremos que unas acciones fueron injustas, otras desmedidas, otras cobardes y otras estúpidas" (Anónimo 1997: 185, III.115). Aunque el desarrollo del tema en esta obra es más profundo que en otras, no deja de descubrirse su raigambre aristotélica.

En Aristóteles, los objetivos del género epidíctico son la virtud, el vicio, lo bello y lo vergonzoso (1999: 240, I.1366a 25-27).

\footnotetext{
Es bello lo que, siendo preferible por sí mismo, resulta digno de elogio; o lo que, siendo bueno, resulta placentero en cuanto que es bueno. Y si esto es lo bello, entonces la virtud es necesariamente bella, puesto que, siendo un bien, es digna de elogio. Por su parte, la virtud es, por lo que parece, la facultad de producir y conservar los bienes y, también, la facultad de procurar muchos y grandes servicios de todas clases y en todos los casos. (Aristóteles 1999: 241-242, I.1366a 33-39)
}

Por su parte, el vicio y lo vergonzoso se definen en relación con estos conceptos primitivos, ya que aparecen como sus opuestos.

La virtud de una persona comprende aspectos como la justicia, la valentía, la moderación, la magnificencia, la magnanimidad, la liberalidad, [la calma], la sensatez y la sabiduría, los cuales, tal y como se verá infra, se manifestarán en las composiciones misóginas del medioevo. En este sentido, Aristóteles parte de que el elogio se hace de las acciones, aspecto que en el discurso ha de aparecer inseparablemente unido a las intenciones (que en este caso serán buenas). Tal intencionalidad tendrá particular énfasis en el pensamiento misógino.

Nociones como lo bello y la virtud están prácticamente identificados con el bien, por lo que, correlativamente, el vicio y lo vergonzoso, con el mal. Esto adelanta una estructura binaria en el pensamiento y los análisis derivados del presente sistema de pensamiento.

Dado que el elogio muestra la virtud, el vituperio ha de mostrar el vicio; y si aquel se refiere a las obras buenas, este, a las malas, uno y otro, aprovechando las circunstancias 
que las rodean, como la nobleza, educación, ascendencia... Téngase presente, como se ha dicho supra, que "Las obras, por su parte, son signos de los modos de ser; por lo que incluso podríamos elogiar al que ninguna ha hecho, si estuviéramos persuadidos de que es capaz $<$ de hacerlas>" (Aristóteles 1999: 250, I.1367b 32-34).

Es decir, mediante la exposición de las obras de un sujeto, por ejemplo, una mujer, conocemos su "naturaleza", las cuales son extrapoladas a todo el género, de manera, que, aunque no las haya realizado materialmente, se le cree capaz de realizarlas.

Por último, sobra decir que la amplificación es el recurso más recomendado para el género epidíctico para cuyo desarrollo recomienda Aristóteles considerar aspectos como su carácter individual o grupal, el tiempo y la ocasión, el número de ocasiones en que tuvo lugar, si hubo originalidad o copia, si fue el primero o no, proceso en el cual las comparaciones con otros sirven principalmente cuando el objeto del discurso no es fuente de material suficiente para la exposición: "La importancia de la amplificación reside en que <se cifra> en la superioridad [... la cual], según parece, revela la virtud" (Aristóteles 1999: 253, I.1368a23-25).

Ahora bien, algunos retóricos, por ejemplo Teón y Aftonio, distinguen un subgénero discursivo semejante al vituperio, se trata del lugar común. Para ellos, el vituperio "se diferencia del lugar común en que el lugar común lleva consigo un castigo, mientras que el vituperio contiene únicamente una acusación pura y simple" (1991: 242.27).

Sin embargo, al tratar de este subgénero se aprecian características más próximas a las composiciones misóginas que las del vituperio, en particular, que el vituperio fue ideado por los retóricos antiguos contra un individuo concreto; y que en el encomio se aportan las pruebas, mientras que en el lugar común, no; tal y como el propio Teón señala (1991: 120.106). De acuerdo con Teón, otra diferencia reside en el proemio, ya que

[...] en el lugar común se pretende dar una impresión tal que parezca que hay un corte y que es una parte de otro discurso pronunciado anteriormente, precisamente como una especia de epílogo enfático de los hechos ya demostrados anteriormente. (1991: 120.106)

\section{En Aftonio,}

es una composición amplificadora de los vicios propios del alguien. Se llama así por ser adecuado comúnmente para todos aquellos que tuvieron parte en la misma acción. En efecto, el discurso dirigido contra un traidor resultó adecuado comúnmente para todos los participantes de la acción. (1991: 232.16)

Ahora bien, una limitación de su examen consiste en que su propuesta está asociada estrechamente al ámbito judicial, ya que versa siempre sobre delitos. Así Teón se refiere continuamente a ladrones, impíos, saqueadores... Empero, pueden rescatarse las siguientes observaciones generales:

\footnotetext{
Es necesario argumentar a partir de la intención de los autores y de la importancia de las obras que realizan, a partir de lo que les ocurre a otros a causa de ellos e, incluso, a partir de lo que ellos obtienen a cambio; y si, como en un proceso, queremos servirnos tanto del proemio como del relato, emprenderemos las argumentaciones después del proemio y de la exposición del delito: en primer lugar, a partir de la intención del autor, diciendo que es malvada; en segundo lugar, a partir del objeto sobre el que se ha cometido el delito, diciendo que es de las cosas más necesarias. [...] Después de esto, a partir del contenido, diciendo que por el nombre el delito es uno solo, pero en realidad contiene en sí muchos delitos: por ejemplo, el adulterio contiene violencia, robo, nacimiento ilegítimo e innumerables faltas más. A continuación, a partir de la comparación, y ésta es triple, pues lo censurado por nosotros lo comparamos con un delito mayor que ello, menor o igual. Así pues, cuando lo comparemos con una mayor, amplificando el menor lo mostraremos igual a aquel [...]. Seguidamente, a partir de los actos anteriores al hecho [...]. A continuación, a partir del resultados y de las consecuencias del hecho [...].
} 
Seguidamente, a partir de su carácter irremediable [...]. Luego, a partir del juicio, o bien de legisladores, o bien de poetas u hombres sabios, diciendo sus opiniones, por ejemplo, que también a éstos les parece que lo realizado es malvado y digno de castigo. Finalmente, haremos la descripción vívida y detallada cuando expongamos el delito como realizándose en el presente (1991: 122.108).

Puede apreciarse que los subgéneros epidícticos del vituperio y el lugar común tienen rasgos semejantes. Ambos se complementan entre sí, para los efectos del presente análisis, pues, aunque por su carácter general el lugar común es más adecuado a la universalidad del sentimiento misógino, el vituperio goza de un desarrollo mayor y más detallado.

\section{Epidíctica y argumentación}

En el modelo aristotélico, las pruebas por persuasión propias del arte proceden del discurso mismo (conviene recordar que estas coexisten con otro tipo de pruebas ajenas al arte retórico, tales como los testigos, confesiones, etc., las cuales, a diferencia de las primeras, "son utilizadas", no "inventadas" por el orador -al respecto, puede consultarse Aristóteles 1999: 174 y ss. I.1355b35 y ss.-). Estas pruebas propias del arte son tres: ethos, pathos y logos. Ethos y pathos (el grado de credibilidad que el orador constituye por medio de su discurso y las pasiones que suscita en el auditorio, respectivamente) corresponden grosso modo a lo que Camacho (2009) denomina como argumentación, es decir, los aspectos psicológicos y sociológicos que intervienen en una interacción argumentativa. Logos, en cambio, es el componente lógico del discurso, en Camacho, los argumentos, aunque desde un punto de vista muy amplio, pues el logos involucra aspectos como la verosimilitud y la probabilidad de las premisas y conclusiones (sobre las nociones de argumentación y argumento, consúltese Camacho 2009: 19).

Para van Eemeren y Grootendorst, "[...] un texto argumentativo es la completa constelación de enunciados (que pueden ser orales o escritos) que han sido presentados en defensa de un punto de vista" (2002: 33). En la argumentación normal, no se encuentran lexicalizadas, es decir, explícitas, todas las premisas, ya que generalmente se recurre a los entimemas, para cuya explicación se han propuestos modelos como el de la existencia de una "regla general" tácita (en este sentido Toulmin comentado por Lo Cascio 1998: 123 ss.), o el de la llamada "regla de paso" (al respecto véase Plantin 2008: 39 y ss.) que fundamenta el tránsito de una afirmación a la conclusión. Por ejemplo, alguien podría sostener de manera argumentativa la siguiente afirmación: Yo no fumo porque fumar es malo. El argumento completo puede expresarse de la siguiente manera:

(1) Fumar es una conducta mala (perjudicial) para la salud.

(2) Debemos evitar las conductas malas (perjudiciales) para la salud.

(3) Por lo tanto, yo no fumo.

En este ejemplo, (1) y (3) fueron condensadas en la expresión original y (2) fue omitida. La oración (2) correspondería a la llama "regla general" o "regla de paso". Este último enunciado, desde un punto de vista lógico, es la premisa que permite el paso de (1) a (3). Es fácil constatar que se trata de una regla general (en este caso, una regla de conducta) que permite, mediante la regla conocida como modus ponens deducir la conclusión.

Nótese que es muy extraño en la argumentación cotidiana que se encuentre un argumento de manera tan explícita. Esto se debe a razones de economía lingüística así como a 
posibles estrategias retóricas (pues expresar todas nuestras premisas las hace más susceptibles de ser atacadas, por ejemplo, debido a que están formuladas de manera muy general o son imprecisas).

La argumentación es un macroacto de habla; en cuanto tal, aprovecha las funciones propias de numerosos actos de habla particulares para defender una tesis, entre los que cabe admitir, por supuesto, el discurso epidíctico. El propio Aristóteles era consciente de esto tal y como se constata en el Libro I de la Retórica al leer:

\footnotetext{
Y puesto que las pruebas por persuasión proceden, no solo del discurso epidíctico, sino también del talante personal (ya que otorgamos nuestra confianza según la impresión que nos causa el orador, es decir, según que parezca bueno o bien dispuesto o ambas cosas. (1999: 239, 1366a 9-12)

Más adelante agrega el pensador de Estagira:

\begin{abstract}
Después de lo dicho, hablemos de la virtud y el vicio y de lo bello y lo vergonzoso, pues éstos son los objetivos <que persigue> el que elogia o censura. Y sucederá, que, al mismo tiempo que tratemos de estas <materias>, se harán evidentes también las <razones> por las que puede comprenderse cuál es nuestro talante; que era <,como dijimos, $>$ la segunda prueba por persuasión. A partir de tales $<$ razones $>$, en efecto, nos será posible, a nosotros mismos y a cualquier otro, presentarnos como dignos de crédito o virtud. (1999: 240, I.1366a 25-29)
\end{abstract}

De lo anterior se colige claramente que ethos, pathos y logos no son "gavetas" discursivas separadas. Son aspectos naturales del discurso que interactúan dialécticamente. Así, el pathos, que fácilmente se asocia al discurso epidíctico, incide tanto sobre el ethos como sobre el logos, y estos afectan a aquel. Esto se constata cotidianamente, por ejemplo, al escuchar o leer un buen elenco de argumentos (logos): el ethos del autor crece ante nuestros ojos y propicia la aceptación de sus tesis. Por el contrario, un mal manejo lógico de un texto convierte a su autor en un mediocre.

Tristemente, tampoco es extraña la experiencia de que se calumnie y denigre a un oponente (pathos) con el propósito de que no se atiendan sus argumentos ni se le escuche (logos).

Por último conviene tener presente para efectos del análisis posterior que para Aristóteles el "talante" se conoce principalmente a través de las intenciones, y estas, a través de los actos (1999: 240, I.1366a 15-16), aspecto que tendrá particular relevancia en la argumentación misógina.

\section{El cuerpo y la argumentación}

Mediante su estrecha conexión con el concepto de "lo bello", objeto propio del discurso epidícto de acuerdo con Aristóteles (1999: 240, I.1366a 25-27), el cuerpo femenino irrumpe, por derecho propio, en la retórica.

En el plano discursivo, su presencia puede tener lugar en cualquiera de las partes del discurso (exordio, narración, demostración y epílogo, según la propuesta del pensador de Estagira).

Tal y como se apuntó supra, la Retórica a Herenio señala que, junto a las circunstancias externas y las cualidades morales, los atributos físicos constituyen uno de los tres grandes aspectos que han de desarrollarse en este tipo de discurso (Anónimo 1997: 181, III.10). Empero, su mayor aporte no consiste en el ornato de la obra, sino en su carácter argumentativo.

Los atributos físicos pueden ser considerados aisladamente, momento en el que cabe destacar si se ha abusado de ellos. Sin embargo, lo más importante en la composición es 
establecer su estrecha correlación con las cualidades morales y las llamadas circunstancias externas. De esta manera, en la narración configurarán uno de los ejes argumentativos. Al respecto, esta obra destaca que debe establecerse una asociación entre el carácter del sujetoobjeto del discurso, sus cualidades físicas, y su conducta, para mostrar cómo se sacó provecho de ellas (Anónimo 1997: 184, III.13).

La lógica de todo lo anterior se basa en que es fundamental el examen de la conducta del sujeto-objeto del discurso, aspecto en el que ha de aprovecharse el concepto de culpa y la noción de "maldad".

Puede apreciarse que mediante el discurso se crea una imagen del sujeto-objeto con ayuda del manejo de su ethos y el pathos que asocia (nótese que en este momento no se emplean estos conceptos en sentido aristotélico) para así dotar de credibilidad a la tesis planteada, la cual, en el discurso misógino será que se debe evitar a las mujeres.

\section{Misoginia literaria}

La misoginia no es extraña en la literatura. El propio Aristóteles en la Retórica manifestaba rasgos que hoy identificaríamos como "machistas" al escribir: "Asimismo son más bellas las virtudes y obras de quienes son por naturaleza más virtuosos, como por ejemplo, las del hombres que las de la mujer" (1999: 246, I.1367a 17-19).

A este respecto, manifiesta cierta ambigüedad el famoso pasaje de Tucídides perteneciente al discurso fúnebre que pone en boca de Pericles, el preclaro gobernante de Atenas:

\footnotetext{
Y si es necesario que me refiera a la virtud femenino, a propósito de las que ahora vivirán en la viudez, lo expresaré todo con un breve consejo: si no os mostráis inferiores a vuestra naturaleza, vuestra reputación será grande, y será grande la de aquella cuyas virtudes y defectos anden lo menos posible en boca de los hombres. (Tucídides 1990: 461, II, 42.2)
}

De un espíritu directamente misógino son los poemas escogidos. Desde el punto de vista de la retórica aristotélica, son de carácter mixto, ya que involucran aspectos propios del género epidíctico, cual el vituperio predominante, junto con el deliberativo, dado que poseen un marcado carácter disuasorio respecto del trato con las mujeres. Esto no es de extrañar, pues para el mismo Aristóteles

\footnotetext{
[...] el elogio y la deliberación son de una especie común, porque, si a lo que se preceptúa cuando se dan consejos se le cambia la expresión, eso mismo resulta un encomio. Y como ciertamente sabemos lo que debemos hacer y cómo debemos ser, basta con que, para dejar esto establecido como un precepto, se le cambie la forma y dé vuelta a la expresión, por ejemplo <diciendo >: "conviene no sentirse orgulloso por lo que a la fortuna se debe, sino por lo que uno hace". Dicho esto así, equivale ciertamente a un precepto, mientras que será un elogio <si dice>: "él no se siente orgulloso por lo que debe a la fortuno, sino por lo que él mismo hace". De manera que cuando se quiere elogiar, hay que ver qué cabría establecer como un precepto; y cuando se quiere establecer un precepto, hay que ver qué es lo que se podría elogiar. La expresión será necesariamente contraria cuando lo que se intercambie sea una prohibición y una no prohibición. (1999: 250-251, I.1367b 38-1368a 9)
}

Efectivamente, los poemas presentan una tesis muy clara: Las mujeres son criaturas malas, de donde se colige, débese evitar a las mujeres, en atención a la regla general débese evitar lo malo, argumento que se puede expresar así:

(1) Si una cosa es mala, se debe evitar.

(2) La mujer es una cosa mala.

(3) Por lo tanto, se debe evitar a la mujer. 
Se trata de un sencillo modus ponens que muestra que el discurso misógino, en este sentido, es apodíctico. Ahora bien, no ha de olvidarse que la validez de un razonamiento no comporta en ningún momento la veracidad de sus premisas.

Esta restricción parece haber sido bien conocida por los autores misóginos, quienes se esmeran sobremanera por demostrar que la mujer es mala. ¿De qué manera lo hacen? A través de la construcción de una imagen negativa de la mujer.

Si bien es cierto la noción de ethos se refiere al orador, en este caso también existe un ethos del objeto del discurso. Con el propósito de modelar una imagen negativa de la mujer, se emplean numerosos recursos estilísticos, tal y como se aprecia en el poema anónimo titulado De artificiosa malitia mulieris (De la hábil malicia de la mujer), poema elaborado a base de dísticos que data posiblemente del siglo XII:

Multa premunt animos et degenerant generosos

Omnibus una magis femina, dulce malum.

Femina, dulce malum, mel fellitum, rosa fetens,

Balsama sero serit, mane venena metit.

Femina, dura quies, inimicus amor, ratus error,

Astuta laqueos simplicitate tegit.

Femina, vile decus, fedus decor, humidus ardor,

Blanditias veteres asperitate novat.

Femina, tota dolus, levitas gravis, ars temulenta,

Nunc veniendo fugit, nunc fugiendo venit.

Femina se vendens et habens, perdens retinensque,

Ipsa sibi merces, ipsa suus fit ager.

Femina, si qua tamen celebs effulserit inter

Milia, clara nimis fit, quia rara nimis.

Muchas cosas agobian y echan a perder a los espíritus generosos,

pero la mayor de todas es la mujer, dulce mal.

La mujer, dulce mal, miel amarga, rosa fétida,

temprano, siembra bálsamos, y en la tarde, cosecha venenos.

La mujer, dura quietud, amor enemigo, ilusión calculada,

con astuta simplicidad cubre sus lazos.

La mujer, vil esplendor, repugnante belleza, húmedo ardor,

renueva ásperamente las antiguas caricias.

La mujer, engaño total, pesada ligereza, arte que embriaga,

ora viniendo huye, ora huyendo viene.

La mujer, vendiéndose se tiene y perdiéndose se retiene,

ella misma es su mercancía, ella misma constituye su patrimonio.

La mujer, si alguna llegara a brillar entre mil por casta,

esa será demasiado excelsa, pues será demasiado rara.

(Rodríguez-Escalona 1995: 130 -las traducciones son del autor de este artículo)

A primera vista destaca el carácter sentencioso de todo el poema. La anáfora femina (la mujer) a partir del segundo dístico, introduce de manera lapidaria las distintas caracterizaciones de la mujer, las cuales comprenden aspectos físicos, morales e intelectuales. Para su enunciación recurre a construcciones paralelas en los dísticos del 2 al 6, de esta forma, en el primer verso 
del dístico (el hexámetro) solo aparecen frases nominales (con la forma sustantivo-adjetivo o viceversa), mientras que en el segundo (el pentámetro) figura un núcleo verbal.

Sus dos primeros dísticos invierten el verso conocido como epanaleptici, es decir, aquellos "Versos en que la primera parte del hexámetro se repite en la segunda del pentámetro" (Herrero Llorente 1971: 118). Nótese que es la segunda parte del primer pentámetro la que se repite en la primera parte del siguiente hexámetro.

La presencia de la rima monosilábica (para este concepto véase infra) es ocasional, en el interior de verso (así animos-generosos (1), serit-metit (4), fugit-venit (10), merces-ager (12), tamen-inter (13) y nimis-nimis (14)) así como al final (generosos-error-ardor (1-5-7), fetensretinensque-ager-inter (3-11-12-13), metit-tegit,venit-minis (4-6-10-14)).

El primer grupo de epítetos (verso 3, dulce malum, mel fellitum, rosa fetens) explota imágenes sensoriales correspondientes al paladar y al olfato. El oxímoron es manifiesto al aprovechar las asociaciones simbólicas de la dulzura, la miel y la rosa con ideas antitéticas. El eje rector de todas estas imágenes ha sido el primer concepto que se arroja contra las mujeres: dulce malum, serán dulces, pero son un mal. Igualmente, pertenecen al ámbito sensorial los elementos del balsama (bálsamos) y venena (venenos), por su orden, el tacto y el gusto.

En cambio, el siguiente dístico alude a conceptos abstractos, tales como quies (descanso), amor (amor) y error (error), los cuales aparecen asociados a la astucia de la mujer representados en una metáfora material, la cual se encuentra en laqueos (los lazos, cuerdas). Tal eje semántico también predomina en los dos dísticos siguientes, aquí representada en decus (gloria, honor), decor (belleza), ardor (ardor), dolus (engaño), levitas (ligereza) y ars (arte). Nuevamente, la vejación de la mujer tiene lugar mediante la adjunción de adjetivos que contradicen las nociones que califican, así, el descanso es duro (dura quies), el amor es enemigo (inimicus amor), la gloria es vil (vile decus), la belleza es sórdida (fedus decor) y la ligereza es pesada (levitas gravis). De esta manera, mediante una experiencia lógica (cual es el oxímoron) se expresa el abuso que cualquier virtud experimenta en manos de la mujer (tal y como la retórica antigua propondría para este caso).

En el curso de esta exposición, aparecen insertos sintagmas como ratus error (engaño calculado), tota dolus (toda engaño) y ars temulenta (arte que embriaga), todos ellos como alusiones a la naturaleza perversa de la inteligencia femenina, la cual se vislumbra amenazadora.

Será en el penúltimo dístico en el que se desarrollen imágenes aprovechando elementos de carácter económico: vendens (la que se vende), habens (la que se posee), perdens (la que se pierde), retinens (la que se retiene), merces (mercancía) y ager (la tierra fértil, cultivable por excelencia, base de la sociedad patriarcal romana).

Por la naturaleza general e indeterminada del ataque, no hay genealogía presente, aunque en otros poemas suele pasarse revista a mujeres famosas por su perversidad, ya sean bíblicas, como Eva (la madre de todo el género), Dalila, Jezabel, Atalia... o míticas, como Erifila, Clitemnestra, Procne y Helena.

Este poema no emplea lenguaje desvergonzado (tal y como recomiendan los manuales) y hace un examen pormenorizado de los vicios.

Tal y como se indicó supra, destaca el paralelismo, en el que cabe citar por el oxímoron nunc veniendo fugit, nunc fugiendo venit.

Una finísima ironía cierra el poema que rescata la imagen de la posible mujer virtuosa, que sería rara avis (ave extraña) en un contexto hiperbólico (inter milia, entre un millar de mujeres).

El poema desarrolla una lógica binaria que disocia el elemento masculino del femenino. Lo masculino sería lo positivo, lo bueno, por lo que lo femenino deviene inexorablemente en lo negativo, lo malo. Esta hace fechorías, aquel es su víctima inocente. 
Este principio informa también el siguiente poema de finales del siglo XII. De autor anónimo, forma parte de un tratado sobre poética dedicado al discurso sobre personas, en el que sirve de exemplum en el curso de la exposición:

Non est persona muliebris digna corona,

Sexus quippe nocens et mala sola docens.

Blanditiis nummum minimum poscit quasi summum;

Blanditiis iuvenes decit atque senes.

Femina lesa furit sed eam quotien dolor urit,

Ore, manu, mente, vultu, mucronibus, igne,

Pandit, miscet, alit, demonstrat, perfodit, urit,

Probra, venena, dolum, feritatem, pignora, tectum.

La persona femenina no es digna de corona,

sexo ciertamente funesto y maestro solo del mal.

Por sus caricias cobra lo mismo el mínimo precio como el máximo.

Con sus caricias engaña a jóvenes y viejos.

La mujer herida enloquece, pero cada vez que el dolor la consume,

con su boca propala injurias, con su mano mezcla venenos,

con su mente alimenta el engaño, con su rostro muestra fiereza,

con sus armas atraviesa a sus seres queridos y con el fuego consume su techo

(Rodríguez-Escalona 1995: 134 -las traducciones son del autor de este artículo)

Este poema, compuesto por dos dísticos elegíacos leoninos seguidos de cuatro hexámetros leoninos, manifiesta ciertos rasgos dignos de rescatar. Como es bien sabido,

\footnotetext{
Fenómenos corrientes en la versificación medieval son también la asonancia y la rima; esta última, al principio, es monosilábica: (dulcem - tristem, sequar-patiar); pero, en la alta Edad Media, la rima llegó a ser de varias letras, e incluso de dos y tres sílabas, y tuvo su mayor apogeo en la poesía rítmica. Sin embargo, el concepto de rima en la Edad Media no se reservó solo para la identidad de sonidos del final de verso, sino que alternaron las rimas en posiciones y modos diferentes; así aparecieron los hexámetros llamados caudati (dos o más versos que riman entre sí), cruciaferi (rimados en cruz), alternati (de rima alternada), e incluso se cultivó con gran entusiasmo la llamada rima leonina, que consiste en una doble rima dentro del mismo verso, dividido en dos hemistiquios que rimam entre sí. La rima leonina se coloca en el hexámetro, por lo general, detrás del tercer tiempo fuerte. (Herrero Llorente 1971: 108)
}

En los dísticos que introducen el poema hay rima leonina polisilábica (personacorona, nocens-docens nummum-summum, iuvenes-senes), mientras que en los hexámetros es monosilábica (furit-urit, mente-igne, alit-urit, dolum-tectum).

El primer dístico opera a manera de exordio. Tal y como prescribe la Retórica a Herenio, se trata de uno directo en el cual se parte de la persona-objeto de que se habla. Mediante una litote (no es digna) y una metáfora (corona) expresa todo el reproche moral canalizado ambiguamente en la palabra sexus, que bien puede representar a la mujer por metonimia o ser una directa referencia a su genitalidad. Esta voz, blanditiis (con sus caricias, versos 3 y 4), ore (boca), manu (mano), mente (mano) y vultu (rostro, 6) son los elementos corporales explotados por el poema. Todos y cada uno de ellos son fuente de males.

Este sexus es el que daña (sentido propio del participio presente nocens) y el que enseña solo males (docens sola mala).

Su boca, su mano, su mente y su rostro están asociados respectivamente a injuria (probra), el veneno (venena), el engaño (dolum) y la ferocidad (feritatem), afectando prácticamente todos los sentidos (el gusto, el oído, el tacto, la vista) y la mente del hombre. 
Como productora de todos estos males, la mujer es fuente de maldad y lo único bueno rescatado, por cierto de carácter físico, como son las caricias, están involucradas con la corrupción, la venalidad de la mujer que se vende, es decir, la prostituta, y el aniquilamiento de jóvenes y ancianos, es decir, los hombres que han llegado a la madurez sexual.

Por su parte, el poema $O$ quanta et qualis est ars istius animalis (¡Oh, cómo y cuán grande es el arte de este animal!), composición anónima de finales del siglo XIII a base de hexámetros leoninos, ofrece una única imagen material de la mujer: la del animal (verso primero). Esta sola caracterización de la mujer contrasta sobremanera con el resto del poema, pues se habla continuamente de que posee un ars, un arte. La irracionalidad de la primera imagen se enfrenta al poder de la segunda, cuya potencia se muestra dominadora sobre los hombres, de quienes se ofrece una breve relación de sabios y reyes caídos, algunos de fuente bíblica (Sansón, Salomón, David), otros, mitológica (Paris, el Atrida). Aquella primera muestra cómo tanto el hombre más fuerte en la tradición hebrea, el más sabio y el soberano más sobresaliente fueron derrotados por mujeres. La argumentación se basa en los exempla (ejemplo) de los cuales, mediante una inducción que evoluciona de lo particular a lo general, extrae una conclusión: cualquier hombre puede sucumbir ante el arte femenino.

Seguidamente, aparece un elenco de mujeres (Catalina, Sara, Bela, Cunegunda...) cuya identidad difícilmente puede precisarse en el mayor número de los casos, junto a los de alguna heroína del Antiguo Testamento como Judith, sin hacer distinción de honores. Se trata nuevamente del argumento mediante exempla que conduce a un razonamiento inductivo, en el que ese arte mujeril está ínsitamente vinculado al mal, el sufrimiento, el engaño, el dolor y la muerte. La conclusión, si bien no apodíctica, es radical: la mujer es una criatura malvada, como lo son sus acciones.

Una curiosa relación entre características físicas y defectos, ya morales, ya en el campo del amor, plantea el poema anónimo Pseudo-Remedia amoris, compuesto en dísticos elegíacos a la manera de los Remedia amoris ovidianos. En el curso de su exposición disuasoria, pasa revista a la mujer que es gorda, flaca, alta, pequeña, blanca, negra, pelirroja, pálida y la de mediana estatura.

De la primera se indica:

Si fuerit pinguis, gravis est ut plumbea massa, mollicie lutea turgida membra tument;

Que cute sudanti velud est axungia porci

lubrica, sepe facit tedia tacta semel.

Si fuera gorda, es pesada como una masa de plomo, sus inflados miembros se hinchan en una despreciable debilidad; la cual con su piel sudorosa es como la resbaladiza grasa del cerdo, a menudo produce repulsión al contacto inmediato.

(versos 5-8, Rodríguez-Escalona 1995: 130 -las traducciones son del autor de este artículo)

La flaca no tiene mayor suerte. Si bien no se le compara con una masa de plomo o los cerdos, ya que

\section{Macra placere nequit, quia pungunt hispida membra exteriusque patent ossa rigente cute.}

La flaca no puede gustar, porque sus miembros hirsutos pinchan y por fuera se ven sus huesos a través de su rígida piel.

(versos 9-10, (Rodríguez-Escalona 1995: 162 -las traducciones son del autor de este artículo) 
De ahí que su amor tenga vocación a extinguirse con prontitud, lo cual se expresa mediante esta comparación: arida ligna quidem cito consumuntur ab igne (verso 11, como los troncos secos son consumidos rápidamente por el fuego).

La alta es comparada con un jumento, animal tenido por insaciable sexualmente; la pequeña, con una serpiente que nos hiere; la blanca, además de que su cuerpo sea frío, marmorea status candidiora putat (verso 24, cree que es más blanca que una estatua de mármol); la que es negra, en cambio, no solo nos tiñe, sino que es inferno similis tenet hec fuliginis instar (verso 27 , semejante al infierno, esta vale cuanto el hollín); la pelirroja, fuego y serpiente que a la vez quema al amante y lo envenena; la pálida, es como amarillenta y semeja a un demonio también.

Aunque la de mediana estatura es la más agradable, su amor es obviamente pernicioso para el autor. En general, el poema recurre al concejo ovidiano a este respecto:

Vadat ad hanc iuvenis ieiunus mane repente,

dum iacet in sopno nuda, soluta caput,

Gaudia tunc sumat, donec fastidia sentit,

quod vult, plus faciat, quam sibi velle fuit.

Post hoc inspiciat, quantum sint turpia membra,

que nulli placeant, si medicina vacet

Valla el joven a ella repentinamente en la mañana,

mientras yace desnuda en su sueño, con el cabello despeinado.

Entonces disfrute todo hasta que se sienta cansado,

lo que quiera, hágalo más de lo que pudo haber querido.

Después vea esto, cuán feos son sus miembros,

los cuales a nadie agradarían si carecieran de cosméticos.

(versos 51-56, Rodríguez-Escalona 1995: 132 -las traducciones son del autor de este artículo)

En su estado natural, el cuerpo femenino se presenta como feo, su belleza es aparente, artificiosa, producto de embustes, de acicalamiento, que ocultan sus innumerables defectos.

En la mayor parte de los poemas, la maldad de la mujer parece asumirse como algo propio de su naturaleza, esta creencia es verificada mediante una elaborada argumentación a partir del examen de su conducta, tal y como la preceptiva clásica dispone, pues el comportamiento de un ser nos permite conocer su carácter.

La misoginia, en este sentido, ofrece un sólido basamento lógico, en el que varias tesis parecen intervenir en su razonamiento: Por un lado, está la premisa general que establece:

Si una persona realiza una acción mala entonces es moralmente culpable.

Junto a esta, se añaden otras dos:

Tentar a una persona es una conducta mala, y

Ser tentado no es una acción.

Sobre esta última puede apuntarse que, en efecto, quien es tentado no realiza una acción en sí misma (a menos que haya buscado la tentación), sino que es objeto de ella, es el sujeto paciente de una oración pasiva como Juan es tentado por María.

De lo anterior se colige que la mujer tentadora deviene en un ser moralmente culpable, mientras que el hombre es una simple e inocente víctima. Esto aunado a la imagen general de la Edad Media que plantea a Satanás como el gran tentador y enemigo del hombre, permite comprender fácilmente cómo la mujer se ve asociada al campo semántico del infierno y el demonio, a la vez que asume la imagen de enemiga del hombre, como también lo es Satanás. 
Corolario de lo anterior, la mujer es descrita como fax Sathane (tea de Satanás, De vita Monachorum, verso 341, Rodríguez-Escalona 1995: 54), fervet y adurit (fuego que hierve y consum, Pseudo-Remedia amoris, versos 29 y 29a, Rodríguez-Escalona 1995: 164) y, en general, será despreciada como vil enemigo.

Sin embargo, el razonamiento parte de una premisa equivocada: asume que toda tentación procede de una acción, cuando lo cierto es que, tal y como los propios escolásticos sabían, derivan de las pasiones, las cuales no son ni buenas ni malas. De este yerro se colige que todas las mujeres son malas, salvo rarísimas excepciones. Esta falta lógica parece haberse querido subsanar con la sintaxis de los poemas, en los que se recurre constantemente a la mujer como sujeto oracional de una oración transitiva, en la que el sujeto paciente es el hombre o sus bienes.

Debido a su posición ideológica (la mujer enemiga mortal del hombre), experimenta un proceso de degradación axiológica. Ella ya no es persona, es animal físico (víbora, loba), mítico (Quimera, Escila, Caribdis, sirena), objeto (fuego que quema, puerto venal, sendero de la muerte, tea de Satanás) o, cuando humana, la agente de acciones perversas o portadora de la muerte. Esta última asociación es una clara degradación del poder generativo de las féminas, poder que, cuando se trae a la memoria por los poetas misóginos, se vincula principalmente a la infidelidad, el adulterio y la lujuria; pero en De fraudulenta muliere (La mujer fraudulenta), se asocia con la muerte física (en clara alusión a la muerte del alma por el pecado):

\section{Primo per veterem mors nos adiit mulierem \\ Que fructum vetitum suasit gustare maritum \\ De quorum nevo mors nostro manat in evo, \\ Ut venit, evelli mors nescia, nescia pelli.}

Primero, por la primera mujer nos llegó la muerte

quien convenció a su marido de gustar del fruto prohibido

por el que la muerte se extiende en nuestro tiempo,

la muerte, que cuando llega, no conoce ser separada, no conoce ser echada.

(Versos 6-9, Rodríguez-Escalona 1995: 114-las traducciones son del autor de este artículo).

\section{Conclusión}

En la poesía misógina, las imágenes del cuerpo femenino desempeñan un papel argumentativo: contribuyen a definir una imagen coherente y definida de la mujer como criatura enemiga del hombre.

La mujer es, para estos poetas, un ser ominoso, ante el cual, solo el conocimiento de su verdadera naturaleza, a través de exempla de muy diversa índole, podría prevenirnos a los hombres de sus peligrosos lazos.

\section{Bibliografía}

Alcidamente de Elea y Anaxímenes de Lámpsaco. 2005. Testimonios y Fragmentos / Retórica a Alejandro. (Intr., trad. y notas por Juan Luis López Cruces, Javier Campos Daroca y Miguel Ángel Márquez Guerrero). Madrid: Gredos.

Anónimo. 1997. Retórica a Herenio. (Intr., trad. y notas de Salvador Núñez). Madrid: Gredos. 
Aristóteles. 1999. Retórica. (Intr., trad. y notas por Quntín Racionero). (2 ${ }^{\text {da }}$ reimpresión). Madrid: Gredos.

Camacho Naranjo, Luis. 2009. Lectura inteligente: la lógica y la literatura en la enseñanza del español. San José: Ministerio de Educación Pública.

Herrero Llorente, Víctor-José. 1971. La lengua latina en su aspecto prosódico -con un vocabulario de términos métricos. Madrid: Gredos.

Lo Cascio, Vincenzo 1998. Gramática de la argumentación. Madrid: Alianza.

Menando el Rétor. 1996. Dos Tratados de Retórica Epidíctica. Madrid: Gredos.

Plantin, Christian. 2008. La argumentación. Barcelona: Ariel.

Rodríguez-Escalona, Mercè Puig. 1995. Poesía misógina en la Edad Media latina. S. XI/XIII. Barcelona: Publicacions Universitat de Barcelona.

Teón, Hermógenes y Aftonio. 1991. Ejercicios de retórica. Madrid: Gredos.

Tucídides. 1990. Historia de la Guerra del Peloponeso. Libros I-II. (1 $1^{\text {a }}$ reimpresión). Madrid: Gredos.

Van Eemeren, Frans H. y Grootendorst, Rob. 2002. Argumentación, comunicación y falacias. Una perspectiva pragma-dialéctica. ( $2^{\mathrm{da}}$ ed.). Santiago: Ediciones Universidad Católica de Chile. 
